\title{
Exclusion of the Filamentous and Rosette-Forming Bacterium "Planctomyces gracilis" Hortobágyi 1965 from the Blastocaulis-Planctomyces Group
}

\author{
MORTIMER P. STARR, ${ }^{1 *}$ KEVIN A. SHORT, ${ }^{2}$ AND JEAN M. SCHMIDT ${ }^{2}$ \\ Department of Bacteriology, University of California, Davis, California $95616,{ }^{1}$ and Department of Botany and \\ Microbiology, Arizona State University, Tempe, Arizona $85287^{2}$
}

\begin{abstract}
The transient occurrence during the summer of 1982 of "Planctomyces gracilis" Hortobágyi 1965, originally described as a planktonic fungus, in two eutrophic man-made ponds in Tempe, Ariz., provided the first recorded sightings of this unusual organism in the United States. A comparison of phase-contrast micrographs prepared from Arizona material with archival descriptions and sketches showed agreement in all respects. Transmission electron microscopy suggested that " $P$. gracilis" is a bacterium rather than a fungus. Notable differences in several traits serve to exclude " $P$. gracilis" from the BlastocaulisPlanctomyces group of budding and nonprosthecately appendaged bacteria. There was no evidence of multifibrillar appendages or crateriform surface structures in " $P$. gracilis"; these are major defining characteristics of the Blastocaulis-Planctomyces group. " $P$. gracilis" is a filamentous and rosette-forming bacterium of unknown taxonomic position.
\end{abstract}

The genus Planctomyces was established by Gimesi (2) in 1924 to accommodate a planktonic "fungus" (Planctomyces bekefii) he had found in a pond in Budapest, Hungary. Subsequently, a number of other "fungal" species were assigned to this genus $(6,13)$. One of these is "Planctomyces gracilis" Hortobágyi 1965 (6). As is required for fungal taxa, the description of " $P$. gracilis" included the following Latin diagnosis (6): "brachia sporifera valde tenuis: 0.3 to $0.4-\mu \mathrm{m}$ crassa, usque ad $11 \mu \mathrm{m}$ longa, raro recta, plerumque parum arcuata. Sporae 0.3 to $0.6-\mu \mathrm{m}$ diametro, globosae." We translate this diagnosis as follows: spore-bearing arms [i.e., conidiophores] are very delicate, 0.3 to $0.4 \mu \mathrm{m}$ wide, up to $11 \mu \mathrm{m}$ long, seldom straight, and generally a little curved. Spores [i.e., conidia] are 0.3 to $0.6 \mu \mathrm{m}$ in diameter and globose. The text explicates the diagnosis with the following information (translated variously from Hungarian and German): differs from the other species [of Planctomyces considered by the author in that paper (6)] on the basis of the thin conidiophores and the tiny spores of " $P$. gracilis"; the diameter of the spores at the ends of the thin conidiophores equals (or is scarcely larger than) the width of the conidiophores. This short description was supplemented by 10 sketches, some of which are reproduced here. This organism was subsequently encountered or mentioned briefly elsewhere $(4,5,7,8)$; relevant information from these reports is found in context below.

The type species of the genus Planctomyces is $P$. bekefii Gimesi 1924. Although it was originally described in 1924 as a planktonic fungus (2), $P$. bekefii is not a fungus; rather, it is identical to a bacterium described under the name "Blastocaulis sphaerica" in 1935 by Henrici and Johnson (3). Various Planctomyces species have been described $(1,5-8$, 12-16). Many of these organisms-including $P$. bekefii and " $P$. gracilis"- -have never been cultivated axenically. As an interim measure, these bacteria are treated by us as morphotypes of a rather heterogeneous Blastocaulis-Planctomyces

\footnotetext{
* Corresponding author.
}

group of bacteria, which have in common the following traits: reproduction by budding, characteristic crateriform surface structures, and at least one major multifibrillar (i.e., nonprosthecate) appendage $(11,13)$.

During the summer of 1982, an organism we believe to be " $P$. gracilis" Hortobágyi 1965 was encountered in two eutrophic man-made ponds in Tempe, Ariz. This rare organism occurred transiently; hence, we were unable to culture it or to obtain the kind of ultrastructural information from the natural samples that we usually secure about such uncultivable bacteria $(10,11,12,16)$. Continued examination of the ponds during the following year, including the entire summer of 1983, did not provide further sightings. Although our observations are not as complete as we might desire, they are sufficient to provide the following: (i) evidence that the Arizona sightings were indeed of " $P$. gracilis" Hortobágyi 1965 ; (ii) some ultrastructural and other characteristics of the organism; (iii) support for the belief that this organism is a bacterium and not a fungus; (iv) grounds for our conviction that this bacterium is not a member of the BlastocaulisPlanctomyces group; and (v) the regretted conclusion that we cannot presently determine to which bacterial group " $P$. gracilis" Hortobágyi 1965 belongs.

\section{MATERIALS AND METHODS}

Water samples. Two highly eutrophic, shallow, man-made ponds in Tempe, Ariz., one wholly within a residential development (The Lakes) and the other in a city park (Kiwanis Park), were the sources of the water samples for the present investigation. The water in both ponds comes via reservoirs and canals from the Salt River Project; both ponds receive runoff from adjacent lawns and streets. Relevant samples were collected early in the mornings (5:30 to 7:00 a.m., Mountain Standard Time) from May through October 1982 from the shorelines of both ponds, at depths of 0.0 to $0.5 \mathrm{~m}$.

Microscopic procedures. Water samples were concentrated 100 -fold by filtration $(0.45-\mu \mathrm{m}$-pore-diameter membrane filters). For phase-contrast microscopy (Nikon Labophot), the concentrated samples were examined without further treat- 
ment. Informative preparations were photographed with the Nikon Microflex AFX system and Kodak TriX Pan (ASA 400) film. For transmission electron microscopy, the grids (copper, 200 mesh, Formvar coated, carbon stabilized) were dipped into the concentrated samples, air dried, and then stained with either uranyl acetate $(1.0$ or $2.0 \%$; $\mathrm{pH} 4.5$ or 5.2 , respectively) or potassium phosphotungstate (usually 1.0 or $2.0 \%$, sometimes $3.0 \%$; $\mathrm{pH} 7.0$ ). The grids bearing the specimens were dipped into the staining solution for $2 \mathrm{~s}$, rinsed with distilled water, air dried, and observed with Philips model EM-201 or EM-300 instruments operated at 60 $\mathrm{kV}$.

\section{RESULTS AND DISCUSSION}

During the course of frequent samplings of the two eutrophic man-made ponds in Tempe, Ariz., from May through October 1982, an organism resembling " $P$. gracilis" Hortobágyi 1965 (6) was observed to occur sporadically. Very little has been reported about this unusual organism, which-like many members of the genus Planctomyces-was originally described as a planktonic fungus (6). Unfortunately, there were not enough rosettes of "Planctomyces gracilis" in these pond water samples, relative to the huge preponder- ance of filamentous cyanobacteria and algae, to allow for a meaningful examination of fixed and sectioned material.

We have no doubt that the Arizona sightings were of the same organism described as " $P$. gracilis" by earlier workers $(4,6-8)$, whose reports were based on light-microscopic observations of pond water samples. Fig. 1A-E shows reproductions of some of the sketches of " $P$. gracilis" prepared by pioneer workers with this organism $(4,6)$; Fig. $1 F$ and $G$ are representative phase-contrast micrographs of our Arizona material. The observable features of the organisms present in our samples were similar to those in earlier descriptions and drawings (Table 1).

Previous publications did not include electron-microscopic observations. Transmission electron micrographs of our material are shown in Fig. 2 and 3. Although the thin sections that would have provided unequivocal evidence to support our argument are not yet available because of inadequate material, the dimensions and other observable features are consistent with the idea $(4,5)$ that " $P$. gracilis" is bacterial in nature, rather than fungal as originally described (6). There was no evidence in the electron micrographs of major multifibrillar appendages or of crateriform surface structures, both of which are essentially invariant
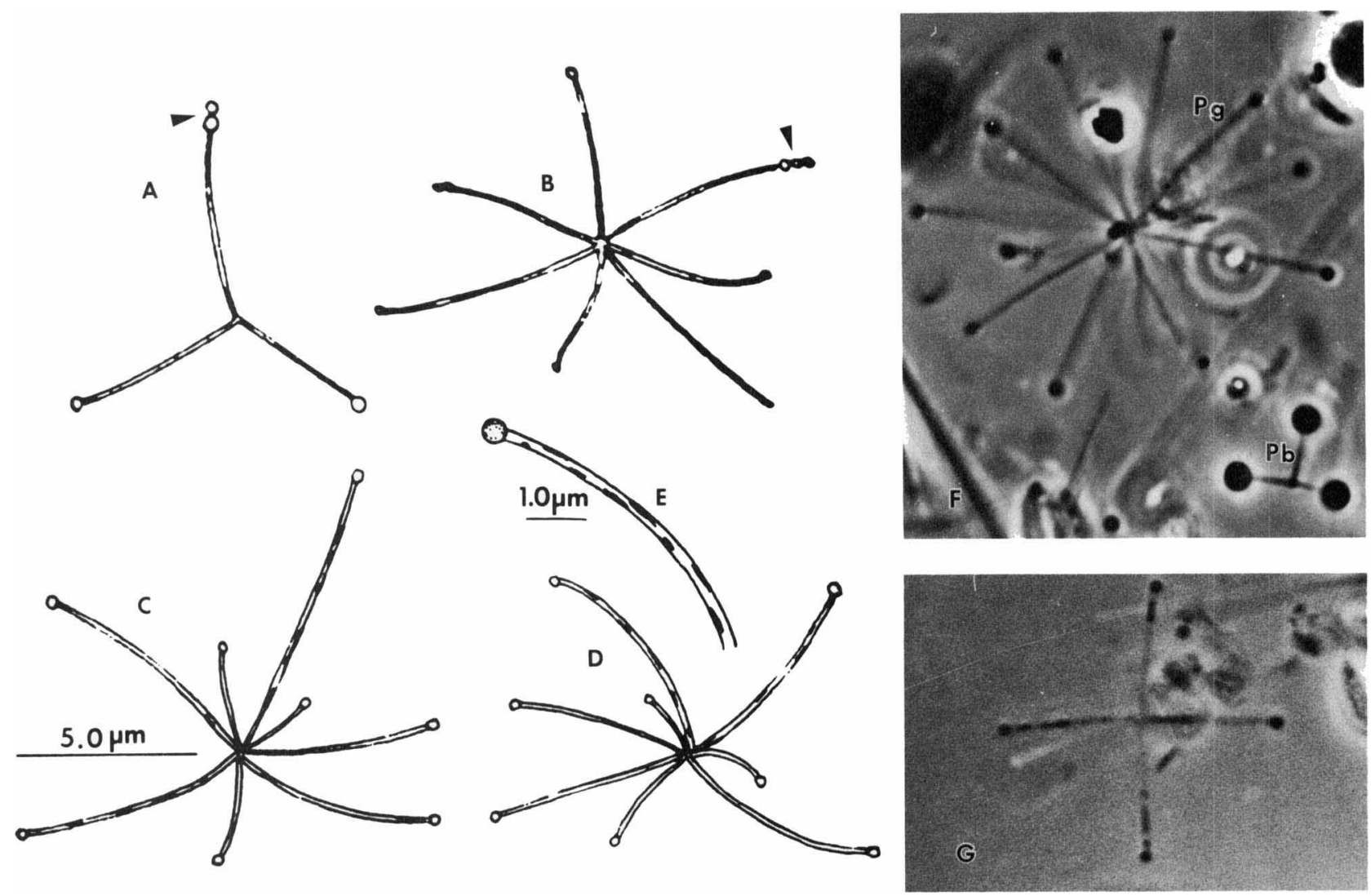

FIG. 1. Archival drawings, which constitute part of the type descriptive material of "Planctomyces gracilis" Hortobagyi 1965, and phasecontrast micrographs of material from the Tempe, Ariz., ponds. (A-E) Line drawings, as presented in references 4 and 6. (A and B) Organisms observed by Hortobágyi in water from a fishpond in Buzák, Hungary (6); multiple spherical terminal units (arrowheads) are depicted on one filament in each drawing. (C-E) Organisms observed by Heynig in water samples from a small reservoir in the Halle District of the German Democratic Republic (4); the filaments show the dense bodies (reproduced at a higher magnification in E). (F and $G$ ) Phase-contrast micrographs of organisms in 100-fold concentrated pond water samples from the Arizona material (the man-made pond in The Lakes, Tempe). (F) Pg, a rosette of " $P$. gracilis" with at least 11 visible filaments (spore-bearing arms in Hortobágyi's mycological terminology [6]); Pb, a small, three-membered rosette of $P$. bekefii Gimesi 1924, the type species of the genus Planctomyces and morphotype Ia of the BlastocaulisPlanctomyces group of budding and nonprosthecately appendaged bacteria (13). (G) Alternating light and dark areas of the filaments (arms) of a rosette. The $5.0-\mu \mathrm{m}$ bar pertains to $\mathrm{A}-\mathrm{D}, \mathrm{F}$, and $\mathrm{G}$; the $1.0-\mu \mathrm{m}$ bar pertains to $\mathrm{E}$. 
TABLE 1. Comparison of the descriptions ${ }^{a}$ of "Planctomyces gracilis" by Hortobágyi (6) and Heynig (4) with our observations on the Arizona material

\begin{tabular}{|c|c|c|c|c|c|c|c|c|}
\hline $\begin{array}{c}\text { Study } \\
\text { (reference) }\end{array}$ & Source & $\begin{array}{c}\text { No. of } \\
\text { filaments } \\
\text { per } \\
\text { rosette }\end{array}$ & $\begin{array}{c}\text { Filament } \\
\text { length } \\
(\mu \mathrm{m})\end{array}$ & $\begin{array}{l}\text { Filament } \\
\text { width } \\
(\mu \mathrm{m})\end{array}$ & $\begin{array}{l}\text { Dense } \\
\text { bodies }\end{array}$ & Metal deposition & $\begin{array}{c}\text { Spherical } \\
\text { terminal } \\
\text { unit }^{b}\end{array}$ & $\begin{array}{c}\text { Diam of } \\
\text { terminal } \\
\text { unit }(\mu \mathrm{m})\end{array}$ \\
\hline Hortobágyi (6) & Fishpond & $3-10$ & 11 & $0.3-0.4$ & Not noted & Not noted & Observed & $0.3-0.6$ \\
\hline Heynig (4) & Reservoir & $8-9$ & $4-6.5$ & $0.3-0.4$ & Observed & Observed $^{c}$ & Observed & 0.8 \\
\hline This report & $\begin{array}{c}\text { Eutrophic } \\
\text { ponds }\end{array}$ & $4-10$ & $5-11$ & $0.3-0.4^{d}$ & Observed & Not observed & Observed & $0.5-0.7$ \\
\hline
\end{tabular}

${ }^{a}$ The terminology in this table differs from the archival terminology. For example, what we call "filaments" are called "spore-bearing arms" or conidiophores in the mycological terminology of Hortobagyi (6) and Heynig (4).

${ }^{b}$ Hortobágyi (6) and Heynig (4), both using mycological terminology, called these structures "spores" (i.e., conidia); we do not know exactly what they are (see text). In one instance (Fig. 2B), we observed two spherical terminal units in a row, an observation also reported (reproduced here in Fig. 1A and B) by Hortobágyi (6). It is uncertain whether this might be the result of a budding process, in the sense that the term "budding" is now used by bacteriologists (1, 5, 11, 13).

${ }^{c}$ Heynig (4) noted: "an einer Kolonie zeigten einselne Träger Andeutungen einer Eiseninkrustation in Form feiner, gelbbrauner 'Striche'."

${ }^{d}$ Mean, 0.38 .

characteristics of the Blastocaulis-Planctomyces group (11, 13).

" $P$. gracilis" appears to be a filamentous and rosetteforming bacterium with rather unusual features. On the basis of our examination of the transmission electron micrographs, we suspect that the filaments (spore-bearing arms, or conidiophores, in Hortobágyi's mycological terminology [6]) of " $P$. gracilis" are either cells or cellular prosthecae, quite different from the multifibrillar (acellular nonprosthecate) appendages of various members of the Blastocaulis-Planctomyces group of budding and nonprosthecately appendaged bacteria $(10-13,15)$.

We could not determine the nature of the spherical terminal units (spores, or conidia, in Hortobágyi's mycological terminology [6]). One (or, in a single case, two [Fig. 2B]) of these spherical terminal units can be seen at the distal (unconnected) end of each filament in our micrographs (Fig. $1 \mathrm{~F}$ and $\mathrm{G}, 2$, and 3). They were also depicted in archival sketches $(4,6)$, some of which are reproduced here (Fig. 1AE). The available material suggests that the spherical terminal units might be (i) cells (with the somewhat narrower filaments being prosthecae), (ii) buds (with the filaments being mother cells), (iii) conidia of the sort found in streptomycetes (with the filaments being generative hyphae), or (iv) even exospores (9) of the kind found in "Methylosinus" spp.

The hairlike devices (Fig. 3A and B) lack multifibrillar substructures. They are often bent or curved, and they protrude in no regular pattern along the filaments. They are ca. 0.3 to $0.4 \mu \mathrm{m}$ long and ca. $20 \mathrm{~nm}$ wide.

The "dense bodies" (Fig. 2A, 2B, and 3C) seem to be
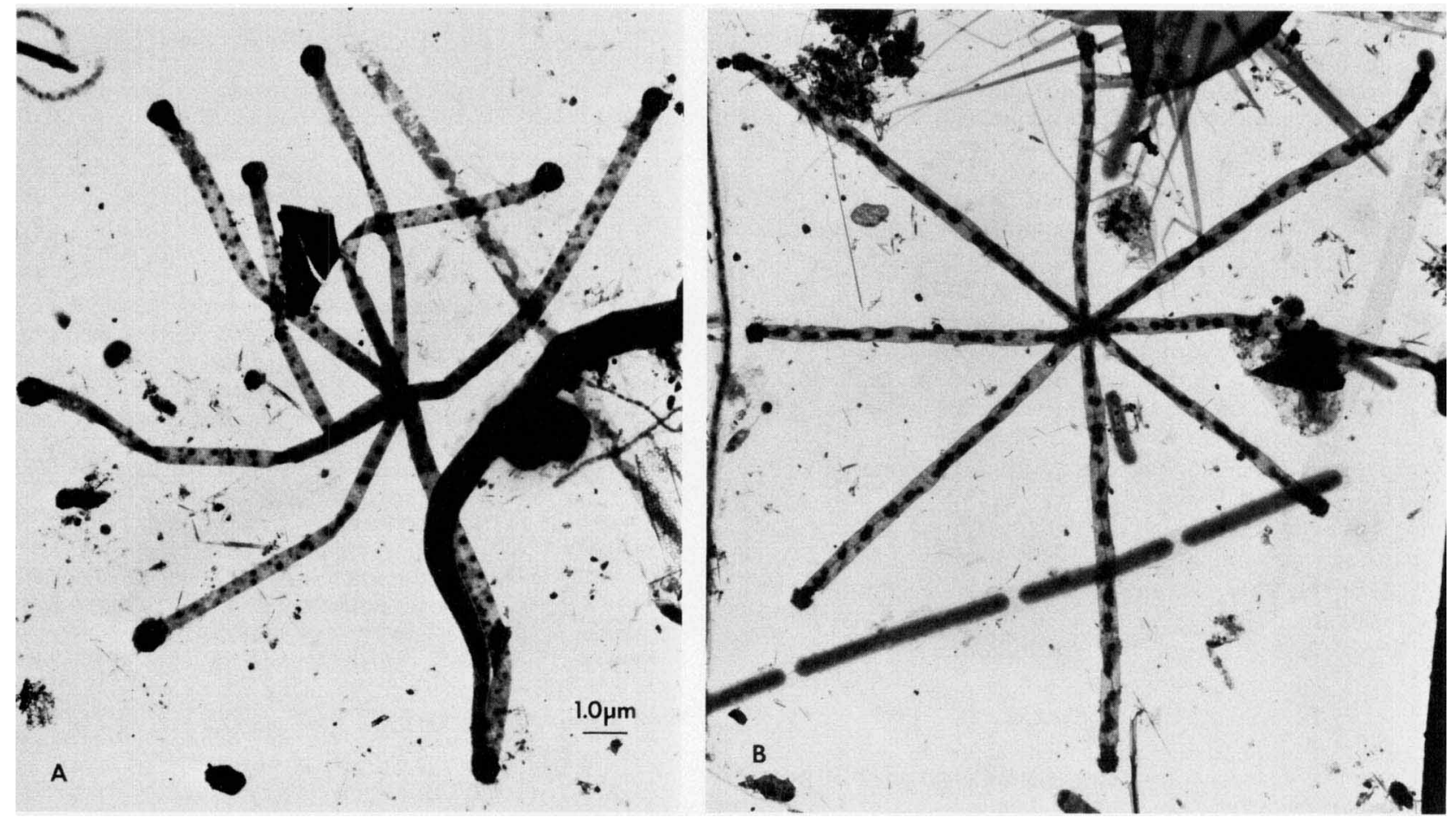

FIG. 2. Transmission electron micrographs of "Planctomyces gracilis" Hortobagyi 1965 rosettes from the Arizona material (the manmade pond in The Lakes, Tempe). (A) Rosette negatively stained with $2.0 \%$ potassium phosphotungstate, showing the shape and distribution of the electron-dense material of the filaments (cf. with Fig. 1). (B) Filaments of an otherwise typical rosette (negatively stained with $1.0 \%$ uranyl acetate) that are less curved than usually observed. The electron-dense structures of the filaments have a pattern different from that in (A). The 1.0- $\mu \mathrm{m}$ bar pertains to both micrographs. 

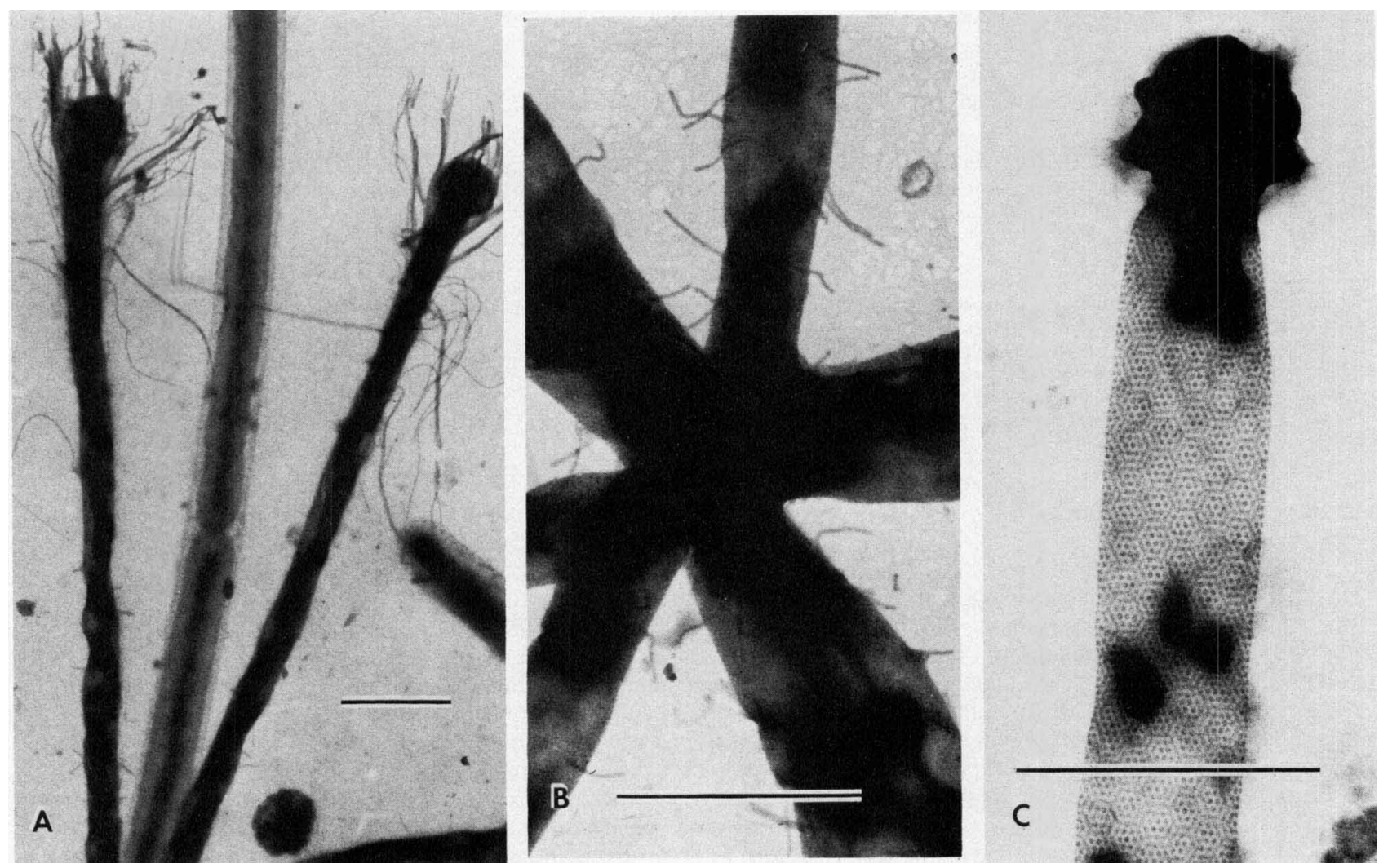

FIG. 3. Transmission electron micrographs of "Planctomyces gracilis" Hortobágyi 1965 from the Arizona material (the man-made pond in The Lakes, Tempe). (A) Portion of a rosette negatively stained with $3.0 \%$ potassium phosphotungstate. In this rosette, the central electrondense region of the filament appeared to be continuous, rather than localized in the unevenly distributed manner shown in Fig. 2A and B. Long, irregular, hairlike fragments are being shed from the filaments, especially in the region of the spherical terminal unit located at the distal end of each filament in the rosette. (B) Central portion of a rosette negatively stained with $2.0 \%$ potassium phosphotungstate. Emanating from the filaments are numerous short, blunt-ended, randomly distributed, hairlike structures. No specialized holdfast was observed at the centers of the rosettes. (C) Filament and terminal unit stained with 1.0\% uranyl acetate. At this higher magnification, the substructure of the filament shows an arrangement of hexagonally packed units, which are much less obvious with potassium phosphotungstate stains. Bars, $1.0 \mu \mathrm{m}$.

electron-dense material inside the outer layer(s) of the filaments. Although they can be visualized by phase-contrast microscopy, they are not refractile, as metallic oxide deposits would be; rather, they contrast with the less dense surrounding material in a manner suggesting that they might be cytoplasmic in nature. The distributions and sizes of these dense bodies in the line drawings of Heynig (4), reproduced here in Fig. 1C-E, are similar to those shown in our material (Fig. 1G, 2, and 3C).

Because the organism was not cultured, appeared only sporadically in the Arizona ponds during 1982, and could not be found at all there during 1983, despite frequent samplings and painstaking examinations, we were unable to learn more about it. Regrettably, we cannot now make a definite taxonomic assignment of " $P$. gracilis" Hortobágyi 1965, other than to exclude it from the Blastocaulis-Planctomyces group.

\section{ACKNOWLEDGMENTS}

This work was supported in part by Public Health Service grant AI-08426 from the National Institutes of Health and grant DEB-7823281 from the National Science Foundation.

\section{LITERATURE CITED}

1. Bauld, J., and J. T. Staley. 1976. Planctomyces maris sp. nov.: a marine isolate of the Planctomyces/Blastocaulis group of budding bacteria. J. Gen. Microbiol. 97:45-55.

2. Gimesi, N. 1924. Hydrobiologiai Tanulmányok [Hydrobiolo- gische Studien]. I. Planctomyces Békefii Gim. nov. gen. et sp. [Ein neues Glied des Phytoplanktons.], p. 1-8. Kiadja a Magyar Ciszterci Rend, Budapest. (In Hungarian, with partial German translation.)

3. Henrici, A. T., and D. E. Johnson. 1935. Studies of freshwater bacteria. II. Stalked bacteria, a new order of Schizomycetes. J. Bacteriol. 30:61-93.

4. Heynig, H. 1979. Einige Bemerkungen und Beobachtungen zur Gattung Planctomyces Gimesi, 1924 (Caulobacteriales) [sic]. Arch. Protistenkd. 122:275-281.

5. Hirsch, P., and H. Skuja. 1974. Genus Planctomyces Gimesi 1924, 4, p. 162-163. In R. E. Buchanan and N. E. Gibbons (ed.), Bergey's manual of determinative bacteriology, 8th ed. The Williams \& Wilkins Co., Baltimore.

6. Hortobágyi, T. 1965. Új Planctomyces fajok. [Neue Planctomyces-Arten.] Bot. Kozl. 52:111-115. (In Hungarian, with German resume.)

7. Hortobágyi, T. 1979. Planctomycesek és algák a Tatai ÖregTóból. Bot. Kozl. 66:143-164.

8. Hortobágyi, T. 1980. Aquatic bacteria and fungi in Danube River and in the water producing systems of the Budapest waterworks. Acta Microbiol. Acad. Sci. Hung. 27:259-268.

9. Reed, W. M., J. A. Titus, P. R. Dugan, and R. M. Pfister. 1980. Structure of Methylosinus trichosporium exospores. J. Bacteriol. 141:908-913.

10. Schmidt, J. M. 1978. Isolation and ultrastructure of freshwater strains of Planctomyces. Curr. Microbiol. 1:65-71.

11. Schmidt, J. M., and M. P. Starr. 1978. Morphological diversity of freshwater bacteria belonging to the Blastocaulis-Plancto- 
myces group as observed in natural populations and enrichments. Curr. Microbiol. 1:325-330.

12. Schmidt, J. M., and M. P. Starr. 1979. Morphotype V of the Blastocaulis-Planctomyces group of budding and appendaged bacteria: Planctomyces guttaeformis Hortobágyi (sensu Hajdu). Curr. Microbiol. 2:195-200.

13. Schmidt, J. M., and M. P. Starr. 1981. The BlastocaulisPlanctomyces group of budding and appendaged bacteria, $\mathrm{p}$. 496-504. In M. P. Starr, H. Stolp, H. G. Trüper, A. Balows, and H. G. Schlegel (ed.), The prokaryotes. A handbook on habitats, isolation, and identification of bacteria. Springer-Verlag, Berlin.

14. Staley, J. T., and J. Bauld. 1981. The genus Planctomyces, p.
505-508. In M. P. Starr, H. Stolp, H. G. Trüper, A. Balows, and H. G. Schlegel (ed.), The prokaryotes. A handbook on habitats, isolation, and identification of bacteria. Springer-Verlag, Berlin, 15. Starr, M. P., R. M. Sayre, and J. M. Schmidt. 1983. Assignment of ATCC 27377 to Planctomyces staleyi sp. nov. and conservation of Pasteuria ramosa Metchnikoff 1888 on the basis of type descriptive material. Request for an opinion. Int. J. Syst. Bacteriol. 33:666-671.

16. Starr, M. P., and J. M. Schmidt. 1984. Planctomyces stranskae (ex Wawrik 1952) sp. nov., nom. rev. and Planctomyces guttaeformis (ex Hortobágyi 1965) sp. nov., nom. rev. Int. J. Syst. Bacteriol. 34:470-477. 